\title{
LEITURA DE ESCRITOS COM O CORPO, DE JOÃO CABRAL DE MELO NETO
}

\author{
A reading of João Cabral de Melo Neto's Escritos com o Corpo
}

Fernando Mendes Pessoa

UFES

Resumo: O propósito deste texto é fazer um diálogo entre filosofia e poesia, através da interpretação do poema Escritos com o corpo, de João Cabral de Melo Neto.

Palavras-Chave: Filosofia, poesia, João Cabral de Melo Neto, Nietzsche, Heidegger

Abstract: The purpose of this text is to make a dialogue between philosophy and poetry, through the interpretation of the poem Writings with the body, by João Cabral de Melo Neto.

Keywords: Philosophy, poetry, João Cabral de Melo Neto, Nietzsche, Heidegger

\section{Introdução}

O pensamento de Martin Heidegger, em seu questionamento sobre a essência da linguagem, deixou como legado para a filosofia a tarefa de fazer um diálogo com a poesia:

Mas pelo fato de a poesia, em comparação com o pensamento, estar de modo bem diverso e privilegiado a serviço da linguagem, nosso encontro que medita sobre a filosofia é necessariamente levado a discutir a relação entre pensar e poetar. Entre ambos, pensar e poetar, impera um oculto parentesco porque ambos, a serviço da linguagem, intervêm por ela e por ela se sacrificam. Entre ambos, entretanto, se abre ao mesmo tempo um abismo, pois "moram nas montanhas mais separadas". ${ }^{1}$

\footnotetext{
${ }^{1}$ HEIDEGGER, M. Que é isto - a filosofia? Em: Conferências e escritos filosóficos. Trad. Ernildo Stein. São Paulo: Abril Cultural, 1979, p. 23. 
Embora morem em montanhas separadas, o oculto parentesco entre filosofia e poesia consiste no fato de ambas nascerem de um mesmo abismo: a linguagem. Como "casa do ser", a linguagem é a abertura para a realidade, onde ela tem a sua realização. Sem linguagem, a realidade nem é, nem não é - não há palavras para dizer o sem linguagem. Esse é o seu mistério: a linguagem é a instância de acontecimento da realidade, onde o ente, o que está sendo, vem a ser o que ele é. Em um nexo fundamental com o ser, o homem também habita a linguagem, existe nessa instância de acontecimento do sendo. Os poetas e pensadores são, para Heidegger, os guardiões dessa habitação; a sua guarda consiste em consumar o nexo que há entre ser e linguagem, trazendo o ser à fala. Filosofia e poesia possuem como tarefa fundamental o desencobrimento desse nexo que manifesta a verdade. Não alguma verdade particular, no sentido de se obter certeza de algo, mas a verdade como desencobrimento do sendo, na qual todo ente se torna mais ente. Verdade é intensificação da realização da realidade pela consumação da linguagem no pensamento: $O$ pensamento consuma a referência do ser à essência do homem, à medida que nele o ser vem à fala. ${ }^{2}$

Conforme Françoise Dastur indicou em seu livro sobre Heidegger ${ }^{3}$, em meados dos anos trinta, o filósofo abandona as questões da fundamentação da metafísica, para se dedicar, até o fim da vida, às questões da linguagem, por duas vias: o estudo do logos no pensamento de Heráclito e Parmênides e da poesia alemã principalmente Hölderlin, quem ele considera ser um poeta de nosso tempo indigente, por fazer poesia da criação poética:

À essência do poeta que, em tal tempo do mundo, é verdadeiramente poeta, pertence o fato de, para ele, de antemão e a partir da indigência do mundo, o poetar e a vocação poética se tornarem questões poéticas. Por isso, os "poetas em tempo indigente" têm que poetar a própria essência da

${ }^{2}$ Cf. Idem, Sobre o humanismo. Trad. Emmanuel Carneiro Leão. Rio de Janeiro: Tempo Brasileiro, 1967, p. 24.

${ }^{3}$ DASTUR, Françoise. Heidegger - La question du logos. Paris: Librairie Philosophique J. Vrin, 2007. 
poesia. Onde isto acontecer, deve-se supor-se um poetar que se conforma com o destino da era do mundo. ${ }^{4}$

Diante deste legado herdado pelo pensamento de Heidegger, João Cabral de Melo Neto se apresenta ao pensamento de língua portuguesa como um poeta exemplar para um diálogo com a filosofia, pois a sua poesia, meta-poética e crítica, é uma fonte ampla e profunda de "poesia em tempo indigente". Em entrevista concedida para Edla van Steen, Cabral disse:

\begin{abstract}
Meu ideal foi sempre ser crítico literário. Ocorre que, aos 17 ou 18 anos, não se tem cultura nem discernimento para ser crítico. Então, eu comecei a fazer poesia, apenas para produzir alguma coisa, enquanto me preparava para a crítica. Muito pouca gente notou isso, mas a minha poesia é quase sempre crítica. Esse negócio que se chama meta-poesia, poesia sobre poesia, é uma preocupação de críticos. $^{5}$
\end{abstract}

A poesia é crítica quando se volta para si mesma com o propósito de pensar a própria criação poética, como fazem Hölderlin e João Cabral. Por essa sua característica fundamental, Cabral colocou em uma de suas coletâneas o título Poesia crítica, na qual, conforme nota introdutória escrita por ele, "reúne os poemas em que o autor tomou como assunto a criação poética e a obra ou a personalidade de criadores poetas ou não".

Somado a essa característica crítica, há também outro fator determinante para propiciar este diálogo com a poesia de João Cabral: o fato de ele escrever com palavras concretas, fazer poesia com coisas: "A palavra concreta é a palavra que você entende pelos sentidos. E a palavra abstrata é a palavra que você atinge pela inteligência. Eu tenho a impressão de que a poesia é uma linguagem que se dirige à inteligência, mas através dos sentidos. Uma palavra concreta é muito mais sensorial do que uma palavra abstrata. ${ }^{6}$ Cabral chega a mostrar a possibilidade de tornar concreta uma palavra abstrata, como fez, por exemplo, em Alguns toureiros, ao tornar os

\footnotetext{
${ }^{4}$ HEIDEGGER, M. Para quê poetas? Em: Caminhos de floresta. Trad. Bernhard Sylla e Vitor Moura. Lisboa: Fundação Calouste Gulbenkian, 2002, p. 312.

${ }^{5}$ STEEN, Edla van. Viver e escrever. Apud. ATHAYDE, Félix de. Idéias fixas de João Cabral de Melo Neto. Rio de Janeiro: Nova Fronteira: FBN; Mogi das cruzes, SP: Universidade de Mogi das Cruzes, 1998, p. 25. ${ }^{6} 34$ Letras, no 3, março de 1989.
} 
substantivos abstratos "tragédia", "vertigem", "emoção" e "susto" concretos, com as suas mensurações aritméticas:

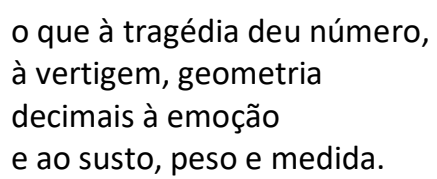

Com essa linguagem concreta, João Cabral busca diminuir a ambiguidade do discurso, promovendo uma compreensão clara, explícita e luminosa do que é dito. Essa luz que propicia uma compreensão clara do que é dito, é o que a filosofia sempre também buscou com o propósito racional de seu discurso. Pois, assim como na filosofia, para João Cabral escrever também é uma ação racional: "Eu não creio que alguém escreva com emoção. Com emoção um sujeito comete um crime, pratica atos irracionais. E escrever é um ato racional."7 Todavia, porque escreve para os sentidos, "A poesia não é linguagem racional, mas linguagem afetiva. Dirige-se à inteligência, sim, mas através da sensibilidade." ${ }^{8}$ A poesia de João Cabral de Melo Neto promove, com sua linguagem concreta e afetiva, uma sensibilidade inteligente que podemos caracterizar como uma razão que não provém da consciência inteligível, mas do corpo - o corpo é uma grande razão.

\section{1) Crítica à compreensão tradicional de corpo}

O título do poema de João Cabral de Melo Neto que vamos interpretar é Escritos com o corpo. O que significa, nesse título, corpo? Tradicionalmente, a filosofia compreende com a palavra corpo "uma coisa extensa em comprimento, largura e profundidade" ${ }^{\prime 9}$. Kant vai usar em sua Crítica da Razão Pura, como exemplo de um juízo analítico, aquele em que o predicado já está contido no sujeito, a frase "o corpo é extenso", pois a extensão é o que caracteriza, necessária e universalmente, todo e

\footnotetext{
${ }^{7}$ Entrevista a Cristina Serra, JL - Jornal de Letras, Artes e Ideias, Lisboa, no 201, 12/18 maio 1986. Apud. ATHAYDE, Félix de. Idéias fixas de João Cabral de Melo Neto, op. cit., p. 28.

${ }^{8}$ Entrevista a Marques Gastão, Diério de Lisboa. Lisboa, 03 maio 1958. Idem.

9 Descartes. Principia I, n. 4, p. 42. Apud. HEIDEGGER, M. Ser e tempo. Trad. Marcia Sá Cavalcante Schuback. Petrópolis: Vozes; Bragança Paulista: Editora Universitária São Francisco, 2006, nota de rodapé no 64, p. 149.
} 
qualquer corpo. Nesta perspectiva, o corpo é uma coisa, um algo pronto e já constituído, aí presente na minha frente, sobre o qual eu posso obter um conhecimento objetivo: o corpo é um objeto que se contrapõe (ob-jecta) ao sujeito. 0 sujeito somos nós, aqueles para quem o objeto, o corpo, se apresenta; porém, nós, os sujeitos, somos também corpo. Todavia, desde a aurora do Ocidente, este corpo foi contraposto metafisicamente ao espírito, à alma, e, assim, condenado a ser um objeto seja da moral - o corpo como "prisão da alma" -, seja da biologia - o corpo como organismo bio-fisiológico. Ambas modalidades de pensamento falam sobre o nosso corpo como se ele fosse apenas uma coisa que pode ser compreendida objetivamente. Como objeto moral ou biológico, o corpo passa a ser algo pronto, "sobre o qual" podem ser descritas e analisadas determinadas características genéricas e universais. Todavia, este corpo "sobre o qual" se fala, não é o corpo que somos, o corpo "a partir do qual" falamos, compreendemos, descrevemos, vivemos. Esse corpo distinto da alma e condenado às funções orgânicas, o corpo objeto da moral e da biologia, já é uma interpretação do que somos que não se funda em uma experiência concreta e efetiva de nós mesmos, mas em idéias, princípios, conceitos. O corpo torna-se uma coisa conceitual: a res extensa, um organismo animal.

O primeiro passo para uma compreensão do sentido de "corpo" no poema Escritos com o corpo de João Cabral de Melo Neto consiste em abandonar essa compreensão preconceituosa do corpo, pois, caso contrário, vamos pensar que ele escreveu este poema com a barriga, ou que usou sangue como tinta em caneta de ossos, ou que ele quis indicar que estes poemas são distintos daqueles escritos com a alma, mais espirituosos... Não! A fim de interpretarmos o sentido de corpo no poema de Cabral, precisamos fazer uma crítica à compreensão tradicional e ganhar uma outra compreensão do corpo, não essa da moral e da biologia, que faz do corpo uma coisa, um objeto contraposto a nós.

Nós somos o nosso próprio corpo, a partir de uma experiência originária de nós mesmos. Ao contrário de um objeto, o corpo é o lugar, a dimensão na qual somos isso que somos, em que existimos; o nosso corpo constitui o horizonte concreto de nossa existência. Como um horizonte existencial, não podemos querer descrever a 
nossa dimensão corporal, a corporeidade ou corporalidade, como uma coisa que está aí, presente fora de mim. Não há como sair do corpo para, estando de fora dele, falar sobre ele. Como horizonte de ser, o corpo é o a partir de onde nós somos, ele constitui uma totalidade sem fora, na qual sempre estamos. Para compreendermos o corpo nele mesmo, ao contrário de falarmos sobre ele, como se o corpo fosse um objeto, precisamos entrar no que somos, imergir na experiência fundamental de nós mesmos, e falar a partir do corpo, deixando a sua descrição aparecer a partir de seu próprio modo de ser, em um escrito com o corpo.

Desde a aurora do Ocidente foi estabelecida a distinção metafísica entre ser e aparecer, tornando-se essência o que permanece sempre idêntico a si mesmo, e aparência, o que é sempre outra. A partir dessa compreensão de essência como o que subjaz a toda transformação, da essência como substância, interpretamos a realidade através de dicotomias de partes fundamentais - sujeito e objeto, verdade e falsidade, bem e mal, etc. e etc. - , sempre correlacionando uma com o ser (a essência) e a outra com o aparecer (a aparência).

Desde essa perspectiva dicotômica da realidade, instaurada pela compreensão da essência como substância, quando dizemos "eu escrevo", geralmente compreendemos que o eu é a causa do escrever, como se o eu tivesse uma essência sub e pré-existente em si mesma, que o torna agente da ação, e essa, a ação, por sua vez, como sendo uma dinâmica proveniente da vontade ou arbítrio desse eu já constituído, o sujeito autônomo da consciência. Mas escrever não é algo que já esteja predeterminado no eu de, por exemplo, João Cabral de Melo Neto. O poeta João Cabral não pré-existe ao ato de escrever, ao escrito; pelo contrário, ele é obra do escrever: é no escrever e pelo escrever que Cabral se faz escritor, torna-se o poeta João Cabral de Melo Neto. Se a origem da obra é o artista, do mesmo modo a origem do artista é a obra, pois alguém só é artista a partir e através de sua obra. Tanto o escritor, quanto o escrito vêm a ser no e por meio do escrever: "um e outro, obra e 
artista, são a possibilidade de ser tomados pela força, pelo verbo, escrever." ${ }^{10}$ Antes de ser um produto do arbítrio do sujeito, escrever é uma dimensão existencial de realização de nossa possibilidade de ser: como ninguém é escritor do poema que não foi escrito, para ser escritor é preciso escrever!

Porque o ser não é distinto do aparecer, a vida não é um substantivo (a substância), mas, antes, verbo. Consequentemente, não há um eu-escritor que sub ou pré-existe antes do escrever: o escrever é a dinâmica de abertura que torna possível escritor e escrito se realizarem, ela é o que os incorpora. Como só há ser no aparecer, a realidade é sempre uma possibilidade que precisa ser incorporada, fazer-se corpo e, assim, tornar-se real, aparecer concretamente. Como ninguém nasce já feito, pronto e acabado, precisamos incorporar o que somos, vir a ser o cumprimento de nossa destinação, concretizando a nossa história na construção sempre inacabada do que se é - a vida se constitui nessa incorporação do que se é, que gera a obra que somos, a nossa história.

Se o eu não sub e pré-existe ao acontecimento existencial de nossas vidas, se a essência (o ser) não possui precedência sobre a aparência (o aparecer), não há João Cabral de Melo Neto antes de sua obra, ele não era escritor antes de escrevê-la. Como origem comum tanto do escritor quanto de sua obra, escrever é o verbo que se apodera, se apropria, se incorpora, tanto de um quanto de outro, fazendo com que ambos venham a ser o que são numa reciprocidade circular e originária. Antes de haver sujeito e objeto, autor e obra, há originalmente o verbo se incorporando em ambos, o corpo da criação se incorporando na criatura.

O corpo é, portanto, o lugar, a instância da ação ou atividade de ser, uma experiência de auto-exposição de si mesmo num agir, verbo: escrever, falar, andar... Como instância existencial do que somos, o que faz o corpo se incorporar e, assim, se apropriar de si mesmo, fazer corpo, é o interesse de vir a ser com propriedade o que se é, um processo de concretização de si no fazer existencial de obra: o interesse é o que conjuga, articula e, assim, unifica o corpo; consequentemente, o desinteresse é o

\footnotetext{
${ }^{10}$ FOGEL, Gilvan. Da pequena e da grande razão (Ou do eu e do próprio). Em: Sentir, ver, dizer. Cismando coisas de arte e de filosofia. Rio de Janeiro: Mauad X, 2012, p. 217.
} 
que fragmenta e dispersa. Nessa instância de acontecimento, com a incorporação do corpo na ação interessada, não há um sujeito dentro e um objeto fora, mas o dar-se em conjunto de homem e mundo em uma reciprocidade original - o corpo é essa unidade do interesse que funda sujeito e objeto no mesmo de sua origem. A essa unidade original do interesse que perfaz o corpo, chamamos de afeto.

O afeto é a experiência de afeição. Não podemos compreender esse fenômeno como algo emocional, psicológico e individual; não é o homem quem tem afeto, mas, ao contrário, o afeto é que tem o homem. "Quer dizer: o homem não é primeiro e antes de mais nada um ou este homem para então, i.é, 'depois' ter ou sofrer um afeto, manifestar uma afecção. Em outros termos: ele não pré- ou sub-existe à experiência, ao afeto." ${ }^{\prime 1}$

$\mathrm{O}$ afeto consiste na experiência de ser tomado pelo que se faz, entrega, dom, doação de se deixar sofrer uma ação. Esse ser tomado por (afeiçoado), o deixar-se assim ser afetado, é o que caracteriza a ação da incorporação do corpo, quer dizer, o processo de crescimento, intensificação, apropriação do que se é. Afeto é escuta, obediência e participação vital do corpo a corpo de homem e mundo, interesse, sintonia, integração, concentração de força, intensificação; e o corpo é essa afecção da criação que proporciona a intensificação de ser, a sua incorporação, encorpoação.

É neste jogo de crescimento e de decrescimento da intensidade ou da participação vital (e que se faz como crescimento e decrescimento de escuta, de 'concentração') que se define o real e que vai se dando ou não a passagem, a trans-posição para a instância de sin-tonização e sin-cronização com o pulso vital e que, ao mesmo tempo, define maior ou menor grau, maior ou menor intensidade de evidência, i.é, de ver, de aparecer, enfim, de realidade e de ser. ${ }^{12}$

O real não é uma coisa pronta e já acabada, mas o que se realiza no jogo da participação vital, como crescimento e decrescimento de sua intensidade conforme a sintonia e sincronia com o pulso vital, com a conjunção do corpo a corpo com o que

\footnotetext{
${ }^{11}$ Idem, ibidem, P. 218.

12 Idem, ibidem, p. 221
} 
aparece, a concentração na conjuntura que evidencia o ser, que reúne e espessa a realidade em seu acontecimento. Como o ser se dá no aparecer, antes de ser uma coisa já realizada, o real só se realiza com a sua realização. O aparecer é a concretização do ser, a sua efetuação real. Uma realidade qualquer só é real se for efetiva, concreta, realizada, feita - e, uma vez efetivada a sua realização, "nem aos deuses foi concedido desfazer o feito". Todavia, por não ser uma coisa feita, a realidade está sempre latente na possibilidade - essa é o horizonte de realização daquela. Como o poder ser lhe é constitutivo, a existência encontra-se sempre aberta, jogada na possibilidade que só se torna real quando realizada. Para ser escritor é necessário escrever, pois não há artista sem obra, aquele que não realizou essa possibilidade existencial e, por isso, não é escritor. Estamos sempre diante do nada de nossa possibilidade de ser, por isso, para sermos o que somos, é necessário realizar, efetuar, vir a ser o que somos. Pedro é pescador porque pesca e João é escritor porque escreve, cada qual é o que é pelo que faz, realiza, efetua. Esse processo de efetuar o que se é constitui a incorporação do que somos, a história que encaminha e orienta o nosso destino: para ser pescador é necessário pescar, mas para ser escritor é preciso escrever: navegar é preciso e viver não é preciso, porque o modo próprio do viver é navegar, ou pescar, ou escrever. A vida é verbo, uma possibilidade que precisa ser realizada, cumprida, encorporada.

Distinto de sua concepção física ou metafísica, biológica ou moral, o corpo é essa incorporação histórico-existencial do que somos, ele é a realização que, se apropriando da possibilidade de ser, efetua uma destinação que the confere identidade: porque pesca, Pedro é pescador; porque escreve, João é escritor. Pescar, escrever, navegar, qualquer verbo, são os modos de realizar a nossa possibilidade de ser - por isso, porque nunca se encontra como um algo pronto, sub e pré-existente, precisamos sempre vir a ser o nosso próprio ser: vida é verbo, encorporação.

\section{Repetição: o corpo como grande razão}

A primeira tarefa para a leitura do poema Escritos com o corpo é fazer uma crítica à concepção moral e biológica de corpo, a fim de ganhar a compreensão de sua 
dinâmica existencial. O corpo não é aqui compreendido em seu sentido físico de animal, um organismo bio-fisiológico, nem metafísico, como "prisão da alma", na tradicional diferença platônica-cristã entre corpo e alma, matéria e espírito. $O$ título do poema indica que o corpo é algo que escreve. Como o título nomeia, o poema, dividido em quatro partes, compõe os escritos com o corpo. Antes da física e metafísica separação entre o corpo, concebido como organismo animal, matéria, sensibilidade, e a alma, como espírito racional, para a compreensão dos Escritos com o corpo faz-se necessário ganhar outra concepção de corpo.

A fim de esclarecer ainda mais essa outra concepção de corpo, chave para nossa interpretação do poema de João Cabral de Melo Neto, encontramos no pensamento de Nietzsche uma crítica ao modo como a tradição filosófica compreendeu o corpo: "O inconsciente disfarce de necessidades fisiológicas sob o manto da objetividade, da ideia, da pura espiritualidade, vai tão longe que assusta - e frequentemente me perguntei se até hoje a filosofia, de modo geral, não teria sido apenas uma interpretação do corpo e uma má-compreensão do corpo."13

A partir da constatação de que até então a filosofia sempre não compreendeu o corpo, Nietzsche, no discurso de Zaratustra intitulado Dos desprezadores do corpo, vai apresentar uma nova concepção de corpo: o corpo é uma grande razão:

\begin{abstract}
"Eu sou corpo e alma" - assim fala a criança. E por que não se deveria falar como as crianças? Mas o homem já desperto, o sabedor, diz: "Eu sou todo corpo e nada além disso; e alma é somente uma palavra para alguma coisa no corpo." O corpo é uma grande razão, uma multiplicidade com um único sentido, uma guerra e uma paz, um rebanho e um pastor. Instrumento de seu corpo é também a tua pequena razão, meu irmão, à qual chamas "espírito", pequeno instrumento e brinquedo da tua grande razão. "Eu", dizes; e ufanas-te desta palavra. Mas ainda maior, no que não queres acreditar - é o teu corpo e a sua grande razão; esta não diz eu, mas faz o eu. (...) Instrumentos e brinquedos são os sentidos e o espírito: atrás deles está ainda o próprio. $\mathrm{O}$ próprio procura também com os olhos dos sentidos, ele ouve também com os ouvidos do espírito. O próprio sempre ouve e procura: ele compara, subjuga, conquista, destrói. Ele domina e é também o dominador do eu. Atrás de teus pensamentos e sentimentos, meu irmão, está um poderoso senhor, um sábio desconhecido - que se chama próprio.
\end{abstract}

\footnotetext{
13 NIETZSCHE, Friedrich. A gaia ciência. Tradução de Paulo César de Souza. São Paulo: Companhia das
} Letras, 2001. Prólogo 2, P. 11. 
Ele mora no teu corpo, é teu corpo. Há mais razão em teu corpo do que na tua melhor sabedoria. ${ }^{14}$

"Eu sou corpo e alma" - assim fala a criança. No pensamento de Nietzsche, "criança" possui o sentido de inocência e esquecimento; um novo começo, um jogo, uma roda que gira por si mesma, um movimento inicial um sagrado dizer sim. ${ }^{15}$ Com inocência, a criança se joga em sua situação de modo puro, sempre no recomeço original de si mesma; com esquecimento, não há ressentimento nem má consciência, métodos ou armações, o que a permite fazer do sim o seu ato criador - criança é o jogo da criação: “Neste mundo, só o jogo do artista e da criança tem um nascer e um perecer, um construir e um destruir sem qualquer imputação moral em inocência eternamente igual."16 $\mathrm{O}$ artista corresponde a este modo de ser criança, mas como homem já desperto que, porque sabe ser todo corpo, concebe a alma como algo do corpo. Ao contrário da pequena razão do espírito, Nietzsche indica que o corpo é uma grande razão.

Conforme a interpretação que Gilvan Fogel faz dessa questão, em seu texto Da pequena e da grande razão ou a respeito do eu e do próprio ${ }^{17}$, nesse discurso de Zaratustra, Nietzsche estabelece um diálogo entre vida - compreendida como vontade de poder, criação - e a tradição - que, aqui na passagem citada, é evocada por 'meu irmão', a qual fala de 'eu' e de 'espírito'. Esse discurso de Zaratustra apresenta uma crítica à interpretação do homem como animal racional, que separando o corpo do espírito, concebe o corpo como sensibilidade animal e o espírito como entendimento racional. A fim de exacerbar o absurdo desta separação metafísica do homem em corpo e alma, Nietzsche inverte a polaridade tradicional, que sempre valorizou o espírito em detrimento do corpo, afirmando que o corpo é a grande razão, a fundamental e, assim, mais importante, maior; enquanto o que chamam de espírito

\footnotetext{
${ }^{14}$ NIETZSCHE, Friedrich. Dos desprezadores do corpo. Em: Assim falou Zaratustra. Trad. Mário da Silva. Rio de Janeiro: Civilização Brasileira, 1986, p. 51.

${ }^{15}$ Idem, ibidem. Das três metamorfoses. Op. cit., p. 44.

${ }^{16}$ Idem. A filosofia na idade trágica dos gregos. Trad. Maria Inês Madeira de Andrade. Lisboa: Edições 70, 1987, p. 49.

${ }^{17}$ Publicado em: Sentir, ver, dizer. Cismando coisas de arte e de filosofia. Op. cit. Utilizo esse texto como orientação para a interpretação que segue do discurso de Zaratustra.
} 
constitui a pequena razão, algo derivado do corpo, seu instrumento e brinquedo. Ao inverter os valores da tradição metafísica, Nietzsche leva a sua história à plenitude de sua realização para, assim, no atravessamento e cumprimento de sua completude, superar a metafísica - acabar com essa divisão que, ao encarcerar o homem em seu eu, impõe uma relação egocêntrica e, por isso, desmedida com o mundo.

O corpo é uma grande razão, uma multiplicidade com um sentido. Ao contrário do pequeno, grande indica aqui o que é fundamental, primordial; ao caracterizar o corpo como grande razão, Nietzsche indica que o fundamento do modo de ser do homem é o corpo. Como grande razão, o corpo é a articulação de sentido que perpassa e unifica a multiplicidade, ele é o que junta e compõe em unidade o que é fragmento, enigma e cruel acaso; o corpo é a força de coesão que concentra a ação no interesse de sua mais plena realização, uma grande razão. Como Fogel indica em seu texto, a razão é um destes conceitos que, de tanto serem usados e abusados, acabam não dizendo mais nada, ficando esquecidos em uma ambiguidade vaga e confusa. Por isso, a fim retirar a compreensão desse lodaçal, é preciso colocar a questão: o que é razão?

Entenderemos por razão o poder, melhor, a força de juntar, compor, integrar ou reunir no próprio ato de ver, i.é, de visualização, entendida esta como o que habitualmente se denomina também a hora ou o ato de apreensão, de captação, de percepção. "Razão" é este ato de ver e ver justo porque já é reunião, integração - compactação. ${ }^{18}$

Distinto da tradicional divisão de corpo sensível e razão inteligível, a fim de compreender o sentido de corpo como grande razão no pensamento de Nietzsche, Fogel indica que a razão é uma sensibilidade inteligente, uma percepção que instantaneamente integra a multiplicidade do que aparece na unidade do sentido. Razão é o modo como apreendemos a realidade, o acontecimento de sua captação imediatamente compactada e integrada na compreensão. Nunca percebemos apenas

${ }^{18}$ Idem, ibidem, p. 212 
estímulos sensíveis, vemos o dia amanhecer e ouvimos o galo cantar. Antes de ser apenas uma recepção da sensibilidade, a nossa visão e audição integram imediatamente o visível e o audível no sentido de uma compreensão: Um galo sozinho não tece uma manhã. A razão é essa articulação imediata do sentido do que sentimos, que sempre apresenta o que aparece de modo articulado, integrado, compactado em uma compreensão de seu sentido. Porque somos racionais, tudo o que aparece já aparece articulado em um sentido, em uma compreensão de seu ser - somos na compreensão do sentido de ser.

Esta compreensão, a razão, não é uma faculdade do homem, um atributo do eu. Por vício do pensamento cartesiano, temos a tendência de nos compreendermos como sujeitos constituídos na consciência de um eu, como uma coisa pré-existente que subjaz em todos os acontecimentos, a res cogitans. Com essa separação entre a nossa essência (ser) e a nossa existência (aparecer), que concebe o eu como uma substância subjacente, o homem se compreende como algo pronto, com uma determinação já dada de modo universal: o homem é o animal (corpo) racional (espírito).

Se razão é força de compactação, poder de articulação do sentido do aparecimento em seu próprio aparecer, ela precisa ser compreendida como força e poder, e não como atributo do homem. Como fundamento original de seu modo de ser, a razão não é arbítrio do sujeito, uma representação de sua consciência; não é o homem quem tem a razão, mas a razão que tem o homem, ela é mais fundamental do que o homem. Por ser força e poder, a razão toma o homem integrando o sentido do que ele vê, escuta, sente. Não há o homem, como algo sub e pré-existente, que tem a razão e, por isso, articula em sua consciência o sentido do aparecimento. Não, esse eu do sujeito é posterior, epigonal, pois a razão é o próprio horizonte onde o eu, e toda a realidade, se realiza, ela perfaz o seu acontecimento. Não há o homem como uma coisa interna e a realidade (o mundo, os outros) como outra coisa externa e distinta antes, por se constituir no horizonte da razão, a realidade do homem sempre se realiza na possibilidade, no acontecimento do que aparece. Não há uma essência anterior à existência; a nossa essência se dá na existência, no acontecimento racional do 
aparecer. A razão é o horizonte de realização de tudo que aparece, o fundamento da manifestação da realidade no sentido de ser.

"Eu", dizes; e ufanas-te desta palavra. Mas ainda maior, no que não queres acreditar - é o teu corpo e a sua grande razão; esta não diz eu, mas faz o eu. A tradição metafísica se ufana do eu, à medida que o concebe como fundamento de toda realidade. Acreditar em um eu como substância pensante, consciência, espírito, é o que alienou o homem de seu corpo e o confinou no que Nietzsche caracteriza aqui como "pequena razão". Desviada de seu fundamento originário, a pequena razão se encapsula numa interioridade solipsista, e se perde na autonomia de seu eu - a coisa (res) pensante (cogitans), o espírito, o sujeito.

Ao contrário de apenas dizer eu, o corpo, como grande razão, faz o eu. Antes de haver um eu subjacente que precede as ações, o eu se faz jogado no imediato acontecimento da vida, na realização que apropria da possibilidade de sua conjuntura. Como a abertura da razão sempre nos apresenta a realidade articulada, organizada, significada, o homem descobre o sentido de ser no instante de seu acontecimento, ele tem a orientação de sua situação lançado no interesse do que está sendo. O homem não é uma coisa que sub e pré-existe ao que ele está sendo, ao seu acontecimento existencial concreto, efetivo. Porque o corpo, como força e poder da grande razão, é o seu fundamento original, o homem descobre a sua essência sendo, fazendo o seu eu ele é o criador de si mesmo.

O próprio sempre ouve e procura: ele compara, subjuga, conquista, destrói. Ele domina e é também o dominador do eu. Mais fundamental do que o eu da pequena razão, Nietzsche indica que o essencial ao homem, a sua grande razão, é o próprio do corpo. Como interesse da conjuntura, o corpo reúne o sentido de ser, compacta, articula e espessa a realidade no instante de seu acontecimento: o corpo é a grande razão. Essa articulação conjuntural da realidade, antes de ser ação de um sujeito, de um eu que sub e pré-existe, se dá numa dinâmica de apropriação de seu acontecimento, que descobre o sentido de ser na compreensão interessada do que 
está sendo. Tal dinâmica de apropriação que articula a conjuntura de modo compacto, espesso, que descobre o sentido de ser no interesse do acontecimento, se constitui como escuta, pertencimento, a participação de ouvir e procurar: ele compara, subjuga, conquista, destrói - compara por avaliar com critério, subjuga porque realiza na possibilidade o seu próprio sentido de ser, conquista porque persevera com coragem e destrói para poder se superar. O corpo, como grande razão, é criação de si mesmo, uma apropriação do eu: atrás de teus pensamentos e sentimentos, meu irmão, está um poderoso senhor, um sábio desconhecido - que se chama próprio.

Antes, atrás do eu e de sua pequena razão, há a apropriação do corpo. Anterior a qualquer estratégia da consciência ou método do entendimento, o corpo, como grande razão, é uma sabedoria que se descobre com inocência e esquecimento, um novo começo, um jogo original; o próprio é o modo como a criança e o artista são. Este sábio é desconhecido porque não possui a sua sabedoria como algo dado, à medida que ela nasce originariamente em um aprender conjuntural. Antes de ser um conhecimento que o sujeito domina, a sabedoria do corpo se mostra na descoberta do interesse da conjuntura, ela se revela na articulação e adensamento do acontecimento que realiza apropriadamente a sua possibilidade - a sabedoria do corpo consiste na apropriação do sentido de ser: há mais razão em teu corpo do que na tua melhor sabedoria: o corpo é uma grande razão.

\section{2) O corpo a corpo entre filosofia e poesia}

Após esta longa advertência introdutória, cujo propósito foi mostrar o corpo como a grande razão da sensibilidade inteligente, do interesse que articula e reúne o sentido da conjuntura em seu próprio acontecimento, vamos ler e, depois, interpretar o poema Escritos com o corpo, de João Cabral de Melo Neto:

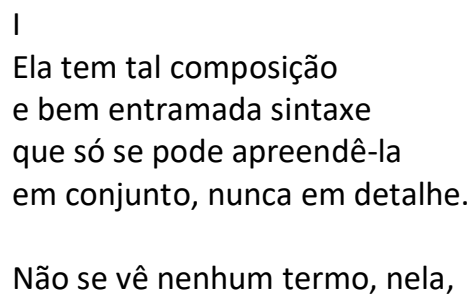


em que a atenção mais se retarde, e que, por mais significante, possua, exclusivo, sua chave.

Nem é possível dividi-la, como a uma sentença, em partes; menos, do que nela é sentido, se conseguir uma paráfrase.

E assim como, apenas completa, ela é capaz de revelar-se, apenas um corpo completo tem, de apreendê-la, faculdade.

Apenas um corpo completo e sem dividir-se em análise será capaz do corpo a corpo necessário a quem, sem desfalque,

queira prender todos os temas que pode haver no corpo frase: que ela, ainda sem se decompor, revela então, em intensidade.

II

De longe como Mondrians em reproduções de revista ela só mostra a indiferente perfeição da geometria.

Porém de perto, o original do que era antes correção fria, sem que a câmara da distância e suas lentes interfiram,

porém de perto, ao olho perto, sem intermediárias retinas, de perto, quando o olho é tato, ao olho imediato em cima,

se descobre que existe nela certa insuspeitada energia que aparece nos Mondrians se vistos na pintura viva.

E que porém um Mondrian num ponto se diferencia: em que nela essa vibração, que era de longe impercebida,

pode abrir mão da cor acesa sem que um Mondrian não vibra, e vibrar com a textura em branco 
da pele, ou da tela, sadia.

III

Quando vestido unicamente

com a macieza nua dela, não apenas sente despido:

sim, de uma forma mais completa.

Então, de fato, está despido, senão dessa roupa que é ela.

Mas essa roupa nunca veste:

despe de uma outra mais interna.

É que o corpo quando se veste de ela roupa, da seda ela, nunca sente mais definido como com as roupas de regra.

Sente ainda mais que despido: pois a pele dele, secreta, logo se esgarça, e eis que ele assume a pele dela, que ela empresta.

Mas também a pele emprestada dura bem pouco enquanto véstia: com pouco, ela toda também, já se esgarça, se desespessa,

até acabar por nada ter nem de epiderme nem de seda: e tudo acabe confundido, nudez comum, sem mais fronteira.

IV

Está, hoje que não está, numa memória mais de fora. De fora: como se estivesse num tipo externo de memória.

Numa memória para o corpo externa ao corpo, como bolsa, Que como bolsa, a certos gestos, o corpo que a leva abalroa.

Memória exterior ao corpo e não da que de dentro aflora; E que, feita que é para o corpo, carrega presenças corpóreas.

Pois nessa memória é que ela, inesperada se incorpora:

na presença, coisa, volume, 
imediata ao corpo, sólida,

e que ora é volume maciço, entre os braços, neles envolta, e que ora é volume vazio, que envolve o corpo, ou o acoita:

como o de uma coisa maciça que ao mesmo tempo fosse oca, que o corpo teve, onde já esteve, e onde o ter e o estar igual fora.

O primeiro passo para entrarmos no poema consiste em compreender o que Cabral caracteriza pelo pronome "ela", que é o assunto, o tema deste poema. Ele diz explicitamente quem é ela na última estrofe da primeira parte do poema, ao escrever:

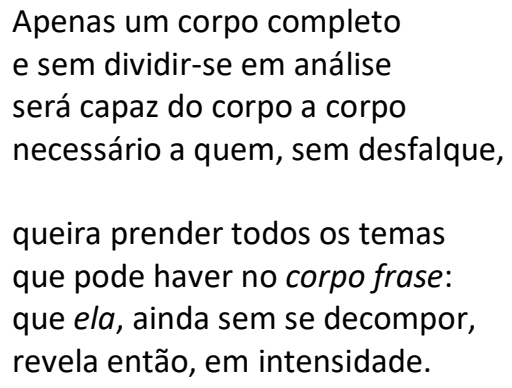

Ela é a frase do poema, o seu "corpo frase". A frase do poema é o verso, o que constitui a sua estrutura elementar. É na composição dos versos, na trama de suas palavras, que o poema torna-se ou não poético. O poético é a força originária, a criação latente na frase da poesia, aquilo que ela só revela em intensidade. Mas, antes de ler o final de sua primeira parte, voltemos ao início do poema, à sua primeira estrofe: 
Considerando que ela é a frase poética, o verso, o poema fala de como se deve escrever e ler poesia, do corpo a corpo necessário a quem queira prender todos os temas do corpo frase. O verso precisa ser composto com o corpo e, o que foi escrito com o corpo, só pode ser lido com o corpo: o tema desse poema é o corpo a corpo do verso com a sua leitura. A primeira estrofe do poema fala de como apreender uma frase com o corpo, a grande razão. Nos quatro versos da primeira estrofe encontramos cinco palavras referentes ao poder da razão, sua compactação e adensamento: composição, entramada, sintaxe, apreender e conjunto - todas indicam o estar reunido, integrado, compactado, espesso e adensado, próprio da grande razão, indicam a sintonia e sincronia do corpo a corpo necessário à leitura do verso. A frase escrita com o corpo compõe a sua sintaxe de modo tão entramado, que só se pode apreendê-la em conjunto, sempre na apreensão completa de seu todo, e nunca em detalhe. Por isso,

\footnotetext{
Não se vê nenhum termo, nela, em que a atenção mais se retarde, e que, por mais significante, possua, exclusivo, sua chave.

Nem é possível dividi-la, como a uma sentença, em partes; menos, do que nela é sentido, se conseguir uma paráfrase.
}

Como a frase escrita com o corpo não é uma sentença, um juízo ou proposição, o seu sentido só pode ser compreendido com a perfeição do corpo completo. Ao contrário das proposições analíticas, com suas divisões e sínteses, a frase poética é originariamente una e, consequentemente, como o seu sentido é sempre elementar, só pode ser compreendida na unidade de seu elemento. Como indicou Heidegger em sua Carta sobre o humanismo, o rigor do pensamento não consiste na exatidão lógica de seus conceitos, mas em manter-se, exclusivamente, no elemento do 
ser, "e deixar vigorar a simplicidade de suas múltiplas dimensões"19. A leitura que pretende apreender a frase poética de fora de seu elemento, utilizando-se somente de divisões analíticas, não vai revelar o sentido da frase; se conseguir, apenas uma paráfrase, algo que só faz uma referência distante ao verso.

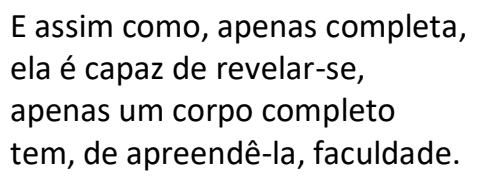

Oculto no ainda não escrito, o verso poético precisa se revelar no exercício de escrever. Antes de ser a ação de um sujeito, o eu da pequena razão, o verso poético é escrito com o corpo, a grande razão que reúne, articula, integra, adensa e espessa o sentido da frase, o que apenas completo é capaz de revelar-se. Completo é o perfeito: como particípio passado do verbo perfazer, completo indica o que se fez todo, pleno, próprio, perfeito. E assim como apenas completo o verso pode se revelar, apenas um corpo perfeito pela leitura pode apreendê-lo. O que foi escrito com o corpo só pode ser lido com o corpo, em uma inteira doação que faculta o verso a se apropriar do acontecimento, enredando o leitor na trama poética do poema, em sua densidade, espessamento, compactação - o que o verso, ainda sem se decompor, revela então em intensidade.

Tendo como tema a possibilidade de ler com o corpo a frase escrita com o corpo, esse poema indica que a leitura poética precisa ultrapassar o poema escrito, as palavras impressas na folha de papel do livro, e abrir-se ao poético latente no verso. 0 que promove a intensidade, a força, o poder de um poema é a poesia. Mas como força e poder, a poesia, o poético de seus versos, não jaz nas frases do poema, mas ao contrário é nelas (frases) que ela (poesia) pulsa, guarda a sua vigência originária, o vigor que, antes de ser entendido por algum tipo de conhecimento analíticosemântico-judicativo, se revela oculto na intensidade do poema. A primeira parte do

19 "O rigor do pensamento se edifica na medida em que seu dizer permanece, exclusivamente, no elemento do ser e deixa vigorar a simplicidade de suas múltiplas dimensões." HEIDEGGER, M. Sobre o humanismo. Op. cit., p. 27. 
poema Escritos com o corpo mostra como deve ser o corpo a corpo entre o escrito e a sua leitura, a fim de indicar como o poético se revela no poema.

\author{
De longe como Mondrians \\ em reproduções de revista \\ ela só mostra a indiferente \\ perfeição da geometria. \\ Porém de perto, o original \\ do que era antes correção fria, \\ sem que a câmara da distância \\ e suas lentes interfiram, \\ porém de perto, ao olho perto, \\ sem intermediárias retinas, \\ de perto, quando o olho é tato, \\ ao olho imediato em cima, \\ se descobre que existe nela \\ certa insuspeitada energia \\ que aparece nos Mondrians \\ se vistos na pintura viva. \\ E que porém um Mondrian \\ num ponto se diferencia: \\ em que nela essa vibração, \\ que era de longe impercebida, \\ pode abrir mão da cor acesa \\ sem que um Mondrian não vibra, \\ e vibrar com a textura em branco \\ da pele, ou da tela, sadia.
}

A segunda parte do poema reforça a necessidade de haver a proximidade do corpo a corpo entre o escrito e a sua leitura, fazendo uma analogia entre o verso e a pintura de Mondrian. Assim como os versos lidos de longe, isto é, sem interesse e distraidamente, de fora de seu corpo, sem se concentrar em seu elemento, também os quadros de Mondrian em reproduções de revistas parecem apenas desenhos geométricos, simples objetos lógicos, sem vida. Porém de perto, na proximidade imediata do corpo a corpo, quando o olho, sem intermediárias retinas - isto é: conceitos, entendimentos, representações que interferem -, quando o olhar é tato, se descobre que há tanto no verso como na pintura de Mondrian a vibração de uma 
insuspeitada energia, a intensidade do que é originário. Aqui também João Cabral se refere ao poético como a força, o poder que a arte oculta em suas obras, o corpo e sua grande razão. Tanto o poema como a pintura guardam o poético da vida, a insuspeitada energia de seu vigor. O poético consiste nessa intensificação do vivo, em descobrir a sua vitalidade original -“a arte resguarda a vida”. Essa vitalidade do poético, que se oculta no verso escrito com o corpo, só pode ser descoberta no corpo a corpo da seda do verso com a pele da leitura, quando a pele do leitor veste a seda do verso.

Por fim, nas duas últimas estrofes, após mostrar a semelhança, Cabral estabelece uma diferença entre a frase poética e a pintura de Mondrian: o fato de ela, a frase, não precisar do suporte da cor para vibrar, à medida que sua intensidade provém da própria palavra. Ao indicar esta diferença, Cabral nos recorda o pensamento aristotélico que compreende ser a ação mais nobre aquela que independe de todo e qualquer outro, podendo ser desempenhada por si e para si. A pintura de Mondrian depende da cor para vibrar, mas o verso não, ele vibra com a textura em branco da pele. Pele é o corpo do leitor, aquele que veste a seda da frase.

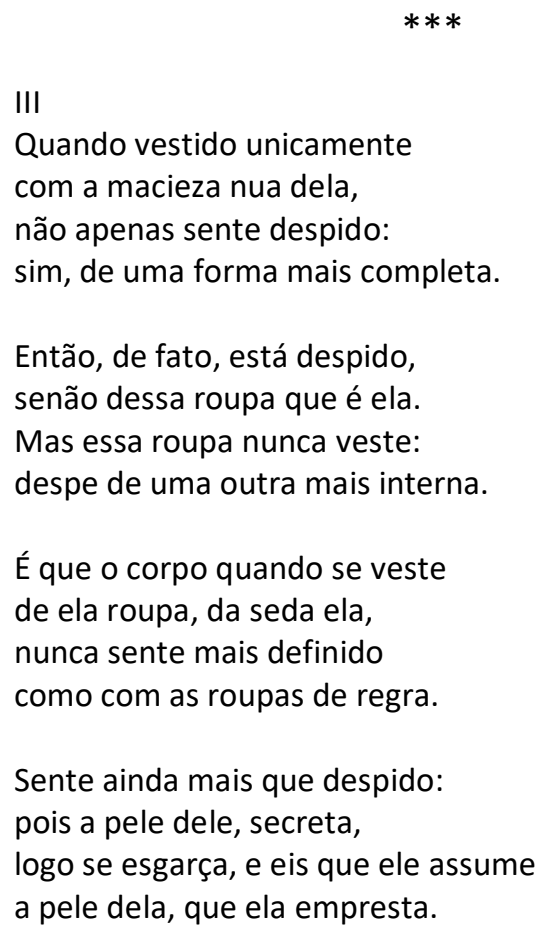




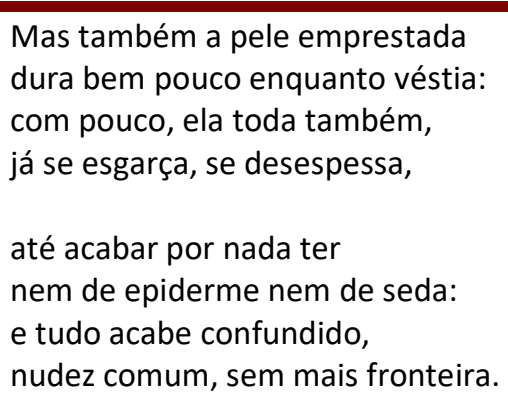

A terceira parte de Escritos com o corpo indica o que ocorre em uma leitura que veste a seda do verso, quando o corpo assume a pele dela, que ela empresta, e entra no elemento da frase poética: ao contrário das roupas de regra, aquelas em que a pele se sente mais definida, essa roupa feita de seda-frase nunca veste, antes despe o corpo-leitor de uma outra roupa mais interna, oculta. No corpo a corpo de poema e leitor não há o eu do leitor, o sujeito, e o outro do poema, o objeto, como dois entes distintos e autônomos, mas a unidade corpórea de origem, a perfeição de sua totalidade como experiência poética. A leitura do poema começa com a encorporação de seus versos: e eis que ele assume a pele dela, que ela empresta. Mas quando o verso é assumido e encorporado, eis que ele também se esgarça, se desespessa, à medida que, quando vestido com a seda da frase poética, o leitor se despe de uma roupa mais secreta, oculta na pele da grande razão de seu corpo. O verso despe o corpo de seu oculto, revelando uma nudez comum, sem mais fronteira, da experiência poética: a unidade de seu uni-verso.

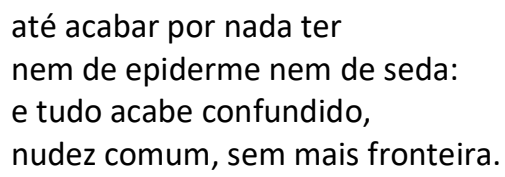

A última estrofe do poema indica a desintegração da diferença entre a peleleitor e a seda-verso, quando em sua travessia o poema se transforma em poesia, deixando de ser os versos impressos em uma folha de livro para tornar-se universo, a totalidade do poético - e tudo acabe confundido, nudez comum, sem mais fronteira. $\mathrm{O}$ corpo a corpo da leitura de um poema se efetua quando a distinção entre pele e seda se confunde na unidade originária da experiência poética. 


\title{
Repetição: A travessia do poema à poesia
}

Heidegger em seu estudo sobre o poema Germânia, de Hölderlin, escreve nesse sentido:

\begin{abstract}
Mas só tal como o próprio poeta se torna senhor e servo da poesia, a saber, por uma luta, é que ganhamos, para além do poema existente, o espaço da poesia. A luta pela poesia no poema é a luta contra nós próprios, na medida em que, na trivialidade quotidiana do ser-aí, estamos expulsos da poesia, estamos sentados na praia cegos, coxos e surdos e não vemos nem ouvimos nem sentimos a ondulação do mar. No entanto, a luta contra nós próprios não significa de modo algum um olhar absorto sobre nós próprios, curioso e analisador da alma, nem uma repreensão 'moral' contrita, antes tal luta contra nós é o trabalho da travessia do poema. (...) Com quanto mais poder a poesia ascende ao poder, tanto mais preemente e arrebatador vigora o dizer da palavra. Só que o poema, nesse caso, já não é a coisa existente, legível e audível que ainda vai sendo, onde a linguagem se considera um meio de expressão e entendimento de que, por assim dizer, dispomos, tal como o automóvel dispõe da sua buzina. Não somos nós quem possui a linguagem, é a linguagem que nos possui. ${ }^{20}$
\end{abstract}

Heidegger indica neste texto a experiência de corpo a corpo entre a peleleitor e a seda-verso, sua encorporação, que promove a travessia do poema para o espaço da poesia. Há uma correspondência entre a atividade do escritor e a do leitor, uma mesma luta contra si próprio para tornar-se senhor e servo da poesia, a luta que permite ao homem ganhar, "para além do poema existente, o espaço da poesia". O poema existente é aquele que lemos nos versos que foram escritos e editados, é a obra efetiva e singular criada pelo poeta. Mas essa obra só é poética se nela se abrir a possibilidade do espaço poético da criação; obra é o que opera a criação: para além do poema (o ente), a obra desvela a poesia (o ser).

Essa travessia do poema para a poesia ocorre pela luta de tornar-se senhor e servo da poesia: "A luta pela poesia no poema é a luta contra nós próprios, na medida em que, na trivialidade quotidiana do ser-aí, estamos expulsos da poesia, estamos sentados na praia cegos, coxos e surdos e não vemos nem ouvimos nem sentimos a ondulação do mar". Desde Ser e tempo, Heidegger sempre indicou como nós temos a tendência de, em nossa lida cotidiana, decair na medianidade do impessoal e, ao

${ }^{20}$ HEIDEGGER. Germânia. Em: Hinos de Hölderlin.Trad. Lumir Nahodil. Lisboa: Instituto Piaget, 2004. 
contrário de compreender e decidirmos o nosso próprio poder ser, adotarmos imperceptivelmente o modo de ser dos "outros", o que Heidegger vai caracterizar como "o impessoal" (das Man). Antes de qualquer avaliação ético-moral, a decadência no impessoal é uma característica constitutiva e essencial de nosso modo de ser, indica como somos numa primeira aproximação e na maioria das vezes. A decadência é a possibilidade de termos um si mesmo impróprio e, ao contrário de exercermos a possibilidade existencial de vir a ser o nosso próprio poder ser, nos compreendemos como um ente simplesmente dado (Vorhandenheit), definido publicamente nas determinações das ocupações. Ao nos compreendermos como um ente simplesmente dado, não nos vemos como possibilidade e esquecemos de ser o nosso próprio ser. Heidegger caracteriza esse fenômeno da perda de si no impessoal como afastamento (Abständigkeit). É esse afastamento de nós mesmos que nos faz estarmos sentados na praia cegos, coxos e surdos, sem ver, nem ouvir, nem sentir a ondulação do mar; é ele que nos expulsa da poesia. Por isso a luta tanto do poeta como do leitor é contra essa tendência de nos afastarmos do que somos e decairmos na trivialidade do cotidiano; é uma luta pela reconquista de nosso próprio ser.

"Mas só tal como o próprio poeta se torna senhor e servo da poesia, a saber, por uma luta, é que ganhamos, para além do poema existente, o espaço da poesia." A luta contra a nossa tendência imediata, de imperceptivelmente adotarmos na maioria das vezes a impessoal trivialidade das compreensões e decisões cotidianas, é que permite ao homem habitar o espaço poético, tornando-se senhor e servo da poesia: “No entanto, a luta contra nós próprios não significa de modo algum um olhar absorto sobre nós próprios, curioso e analisador da alma, nem uma repreensão 'moral' contrita, antes tal luta contra nós é o trabalho da travessia do poema".

A travessia do poema para a poesia se dá no corpo a corpo entre a pele-leitor e a seda-verso, na encorporação do corpo frase que nos conduz do poema ao espaço da poesia. Como indicou João Cabral de Melo Neto, em seu poema Escritos com o corpo, quando vestimos unicamente a macieza nua da seda-verso, ao contrário de nos vestir, de uma forma mais completa, ela nos despe de uma outra mais interna. Vestido com a seda-verso, o corpo nunca se sente mais definido, como com as roupas de regra. 
A travessia do poema para a poesia é sempre uma experiência de estranhamento, por nos conduzir ao abandono de nossas compreensões triviais, uma luta contra a tendência de nos afastarmos do que somos, que concentra e intensifica a realidade: "Com quanto mais poder a poesia ascende ao poder, tanto mais preemente e arrebatador vigora o dizer da palavra":

\author{
Apenas um corpo completo \\ e sem dividir-se em análise \\ será capaz do corpo a corpo \\ necessário a quem, sem desfalque, \\ queira prender todos os temas \\ que pode haver no corpo frase: \\ que ela, ainda sem se decompor, \\ revela então, em intensidade.
}

A intensidade de um poema se revela na força arrebatadora do verso poético, na possibilidade de ele promover um deslocamento das trivialidades cotidianas e nos levar à experiência da extraordinária intensidade que pode haver no corpo frase, a travessia do poema para o espaço da poesia. Por isso, na leitura de um poema, o leitor precisa sentir-se despido de sua roupa habitual para vestir completa e unicamente a roupa dela, da seda-verso:

\footnotetext{
Mas também a pele emprestada

dura bem pouco enquanto véstia:

com pouco, ela toda também,

já se esgarça, se desespessa,

até acabar por nada ter

nem de epiderme nem de seda:

e tudo acabe confundido,

nudez comum, sem mais fronteira.
}

A travessia do poema para o espaço da poesia não mostra isso ou aquilo (um ente), mas revela a própria unificação de ser e linguagem, a nudez comum, sem mais fronteira, do corpo: "Não somos nós quem possui a linguagem, é a linguagem que nos possui." No arrebatamento dessa hora, o poema já não é mais a coisa existente, legível 
e audível, mas o que revela a linguagem como morada do ser. O poema escrito com o corpo indica a experiência de travessia poética da linguagem, a sua encorporação.

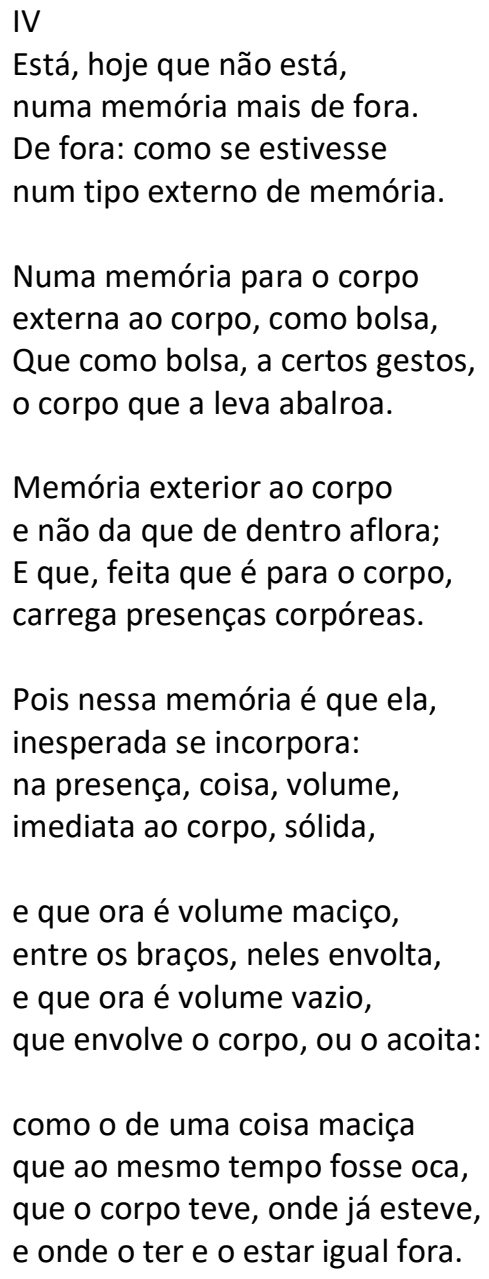

$\mathrm{Na}$ quarta e última parte do poema Escritos com o corpo, Cabral fala da memória que uma ação desempenhada com a grande razão do corpo nos promove. Essa recordação não é uma lembrança de algo, um fato, uma coisa, alguém; essa memória é a lembrança de um experiência poética, a memória afetiva de sua intensidade vital.

Está, hoje que não está,

numa memória mais de fora.

De fora: como se estivesse

num tipo externo de memória. 
A primeira estrofe fala da memória que a afeição do corpo a corpo entre a pele-leitor e a seda-verso nos promove quando, após travessia do poema ao espaço poético, voltamos para a nossa trivialidade cotidiana: hoje que não está. A experiência de travessia do poema para o "espaço poético" nos transforma, abala a nossa compreensão cotidiana da realidade, suspendendo toda a trivialidade da vida; tal experiência ocorre com o espanto diante do extraordinário, que se revela em intensidade. Essa transformação não se realiza por arbítrio da vontade, nem se mantém por meio de consciência subjetiva; mas é dom, dádiva da criação. Por isso ela não é posse do homem, mas um tipo externo de memória.

\footnotetext{
Numa memória para o corpo externa ao corpo, como bolsa, Que como bolsa, a certos gestos, o corpo que a leva abalroa.
}

Uma memória que, apesar de ser para o corpo, não é do corpo, que ele a leva consigo, podendo ser abalroado por ela. Embora essa memória provém da experiência de corpo, de sua encorporação, a sua recordação não está sob o domínio do homem, à disposição do arbítrio de sua vontade. Por isso ela vem ao encontro daquele que por ela espera de forma dadivosa e abalroa o corpo. Abalroar é ir ao encontro de algo e se chocar com ele, colidir. Indica um ser avassalado pelo que vem ao encontro e se choca, sendo, portanto, sempre um encontrar, e nunca um procurar.

\footnotetext{
Memória exterior ao corpo

e não da que de dentro aflora;

E que, feita que é para o corpo carrega presenças corpóreas.
}

Uma memória distinta da que de dentro do corpo aflora, isto é, diferente das lembranças que temos de algo, um fato, uma coisa, alguém. Mas como ela é feita para o corpo, a sua lembrança se dá como encorporação. Não é lembrança de algo, de uma criatura qualquer, mas da intensidade da própria criação, que precisa ser encorporada no corpo a corpo de uma ação. Escrever com o corpo não é uma ação proveniente do 
que Nietzsche chamou de "pequena razão", a saber, algo que possa ser dominado por alguma representação da consciência. A ação do corpo, como vimos, é uma doação ao próprio corpo, à sua grande razão. Embora seja impossível a sua dominação, cabe ao homem cuidar dessa memória, recordando da possibilidade de sua experiência.

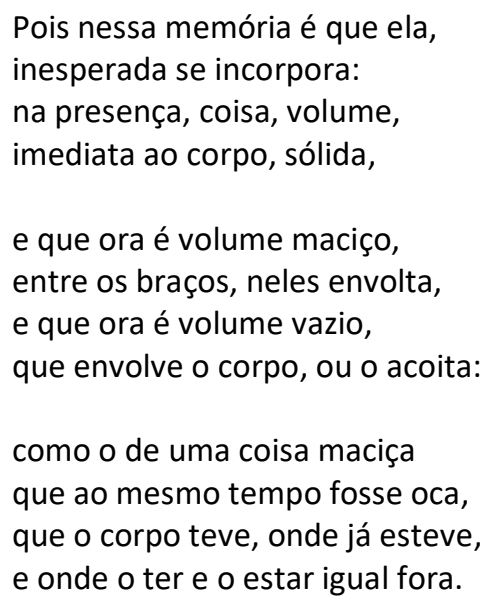

Pois somente com esse cuidado que, sem deter e nem abandonar, pode o homem cultivar a encorporação do verso, pois é nessa memória que ela, a frase, inesperada se incorpora. Para que essa experiência poética ocorra, é preciso esperar o inesperado que subitamente se encorpora, faz-se corpo presente, coisa, sólido volume, mas que embora seja maciço é igualmente oco. Esse é o mistério da criação; o fato de isso que é o mais denso e intenso, mais compacto, mais maciço e espesso ser simultaneamente o mais etéreo, mais fugas, mais imponderável - como uma coisa maciça que fosse ao mesmo tempo oca. O mistério é o que compreendemos sem jamais entender, isso que para ser compreendido é necessário ser iniciado: algo que o corpo, por jamais deter, só pode ter quando estar. Cabral termina o seu poema indicando que o trabalho poético é o cuidar de um mistério, o cultivo de uma memória que, embora não a dominamos, pode se apropriar do corpo e se encorporar em poesia, como um volume vazio que envolve e acoita. O poema de João Cabral de Melo Neto nos ensina como ler escritos com o corpo. 


\section{Referências bibliográficas}

DASTUR, Françoise. Heidegger - La question du logos. Paris: Librairie Philosophique J. Vrin, 2007.

Descartes. Principia I, n. 4, p. 42. Apud. HEIDEGGER, M. Ser e tempo. Trad. Marcia Sá Cavalcante Schuback. Petrópolis: Vozes; Bragança Paulista: Editora Universitária São Francisco, 2006, nota de rodapé no 64, p. 149.

FOGEL, Gilvan. Da pequena e da grande razão (Ou do eu e do próprio). Em: Sentir, ver, dizer. Cismando coisas de arte e de filosofia. Rio de Janeiro: Mauad X, 2012.

HEIDEGGER, M. Germânia. Hinos de Hölderlin. Trad. Lumir Nahodil. Lisboa: Instituto Piaget, 2004.

HEIDEGGER, M. Para quê poetas? Em: Caminhos de floresta. Trad. Bernhard Sylla e Vitor Moura. Lisboa: Fundação Calouste Gulbenkian, 2002.

HEIDEGGER, M. Que é isto - a filosofia? Em: Conferências e escritos filosóficos. Trad. Ernildo Stein. São Paulo: Abril Cultural, 1979.

HEIDEGGER, M. Sobre o humanismo. Trad. Emmanuel Carneiro Leão. Rio de Janeiro: Tempo Brasileiro, 1967.

NIETZSCHE, Friedrich. A filosofia na idade trágica dos gregos. Trad. Maria Inês Madeira de Andrade. Lisboa: Edições 70, 1987.

NIETZSCHE, Friedrich. A gaia ciência. Tradução de Paulo César de Souza. São Paulo: Companhia das Letras, 2001.

NIETZSCHE, Friedrich. Dos desprezadores do corpo. Em: Assim falou Zaratustra. Trad. Mário da Silva. Rio de Janeiro: Civilização Brasileira, 1986.

STEEN, Edla van. Viver e escrever. Apud. ATHAYDE, Félix de. Idéias fixas de João Cabral de Melo Neto. Rio de Janeiro: Nova Fronteira: FBN; Mogi das cruzes, SP: Universidade de Mogi das Cruzes, 1998. 